\title{
Fishery regulamentation or ethnoknowledge? The dilemma of the management of the mapará fisheries on the lower Tocantins river in northern Brazil
}

\author{
Regulamentação pesqueira ou etnoconhecimento? Dillema do manejo da pesca do mapará no baixo \\ Tocantins \\ ¿Regulación pesquera o conocimiento étnico? Dilema de la gestión de la pesquería de mapará en el \\ bajo Tocantins
}

Received: 08/02/2021 | Reviewed: 08/10/2021 | Accept: 08/24/2021 | Published: 08/25/2021

Esther Mirian Cardoso Mesquita ORCID: https://orcid.org/0000-0002-4392-3177 Universidade Federal do Pará, Brazil E-mail: esther_shekinah@hotmail.com

Paulo Allison Costa da Mata ORCID: https://orcid.org/0000-0001-5898-1321 Universidade Federal do Pará, Brazil E-mail: pauloomata@gmail.com

Matheus dos Santos Souza

ORCID: https://orcid.org/0000-0002-7753-5877 Universidade Federal do Pará, Brazil E-mail: omattmatheus@gmail.com

Maria Clara Pinheiro de Souza

ORCID: https://orcid.org/0000-0003-1070-9892 Universidade Federal do Pará, Brazil E-mail: clarasouza.bio@gmail.com

Victoria Isaac

ORCID: https://orcid.org/0000-0002-7652-2708 Universidade Federal do Pará, Brazil

E-mail: biologiapesqueira@hotmail.com

\begin{abstract}
The fishery of mapará (Hypophthalmus marginatus) is of great economic importance in the Amazon region. Despite this, it is observed that the current norms of management disagree with the ethnoknowledge of fishermen of the Tocantins river. Therefore, there are many seizures and fines in the Tocantins Low region. This work appeared as a demand of the fishermen of the region and had as purpose to test the pertinence of the fishing legislation on the capture of the species and to provide subsidies for the adaptation of the norms to the local reality. For this, a mapará fishery was taken on the Pindobal Grande river, in the municipality of Igarapé-Miri, in the state of Pará. A sample of the captured individuals was collected, and identification, sexing and biometry were done. Fishing was described, and the sex ratio tested with the Chi-Square test and the mean length differences between the sexes with the Student's t-test. The results were compared with current legislation and literature data. The captured mapará individuals were mostly above $30 \mathrm{~cm}$, as determined by legislation. It is concluded that, despite using a network that is prohibited, the capture of the species in the region acts selectively, due to the ethno-cognition and the fisherman's action ("taleiro"). Therefore, it is necessary that the legislation be revised, seeking the reconciliation between the conservation of ecosystems, the traditional knowledge and the socioeconomic development of the region.
\end{abstract}

Keywords: Selectivity; Legislation; Sustainability; Amazon; Traditional knowledge.

\section{Resumo}

A pescaria do mapará (Hypophthalmus marginatus) é de grande importância econômica na região amazônica. Apesar disso, observa-se que as normas de manejo vigentes estão em discordância com o etnoconhecimento dos pescadores do rio Tocantins. Logo, há uma grande quantidade de apreensões e multas na região do Baixo Tocantins. Este trabalho surgiu como demanda dos pescadores da região e teve como finalidade testar a pertinência da legislação de pesca sobre a captura da espécie e fornecer subsídios para a adequação das normas à realidade local. Para isso acompanhou-se uma pescaria do mapará no rio Pindobal Grande, município de Igarapé-Miri, estado do Pará. Retirou-se uma amostra dos indivíduos capturados, e foi feita a identificação, sexagem e biometria. A pesca foi descrita e a proporção sexual testada com o teste de Qui Quadrado e as diferenças do comprimento médio entre os sexos com o teste t de Student. Os resultados foram comparados com a legislação vigente e com dados da literatura. Os indivíduos de mapará capturados estavam em sua maioria acima dos $30 \mathrm{~cm}$, determinado pela legislação. Conclui-se então, que apesar de utilizar uma 
rede que é proibida, a captura da espécie na região atua de forma seletiva, por conta do etnoconhecimento e da atuação do pescador ("taleiro"). Logo, faz-se necessário que a legislação seja revista, buscando a conciliação entre a conservação dos ecossistemas, o saber tradicional e o desenvolvimento socioeconômico da região.

Palavras-chave: Seletividade; Legislação; Sustentabilidade; Amazônia; Conhecimento tradicional.

\section{Resumen}

La pesca del sorgo (Hypophthalmus marginatus) tiene una gran importancia económica en la región amazónica. Sin embargo, se observa que las normas de gestión vigentes están en desacuerdo con los conocimientos étnicos de los pescadores del río Tocantins. Por lo tanto, hay un gran número de incautaciones y multas en la región del Bajo Tocantins. Este trabajo surgió como una demanda de los pescadores de la región y su objetivo era comprobar la pertinencia de la legislación pesquera sobre la captura de la especie y proporcionar subvenciones para adaptar la normativa a la realidad local. Así, seguimos una pesquería de mapará en el río Pindobal Grande, municipio de Igarapé-Miri, estado de Pará; donde se tomó una muestra de los individuos capturados y se procedió a su identificación, sexado y biometría. Se describieron las pesquerías y se comprobaron las proporciones de los sexos con la prueba de Chi Cuadrado y las diferencias de longitud media entre los sexos con la prueba t de Student. Los resultados se compararon con la legislación vigente y con los datos de la literatura. La mayoría de los ejemplares de mapará capturados superaban los $30 \mathrm{~cm}$, tal y como exige la ley. Se puede concluir que, a pesar del uso de una red prohibida, la captura de la especie en la región es selectiva, debido al conocimiento étnico y a las acciones del pescador ("taleiro"). Por lo tanto, es necesario que se revise la legislación, buscando conciliar la conservación de los ecosistemas, los conocimientos tradicionales y el desarrollo socioeconómico de la región.

Palabras clave: Selectividad; Legislación; Sostenibilidad; Amazonia; Conocimientos tradicionales.

\section{Introduction}

The mapará, Hypophthalmus marginatus (Valenciennes, 1840), is a medium-sized catfish of the family Hypophthalmidae, which is found in South America, in the basins of the Amazon and Orinoco rivers, as well as many other, smaller rivers in French Guiana and Suriname (Lundberg \& Littmann, 2003). Hypophthalmids are pelagic fish that typically have rheophilic habits, that is, they prefer areas of running water (Carvalho, 1980). The genus Hypophthalmus can be distinguished from other freshwater catfish by the position of the eyes, which are located lateroventrally, in the middle of the head (Costa, Oshiro \& Silva, 2010).

The mapará can be found in both lakes and river channels. Like other catfish, the mapará forms shoals, which travel along the river (Lowe-Mcconnell, 1987; Barthem \& Goulding, 1997). As a migratory species, peaks in the catches of $H$. marginatus occur progressively further upstream as the shoals move upriver to spawn (Juras et al., 2005).

Maparás are specialized for the filtering of plankton, with a highly modified buccal morphology adapted for filtering. These fish filter passively as they move through the water, that is, they swim with the mouth open and opercula dilated, with prey being selected according to the size of the branchial filter (Carvalho, 1980; Abelha et al., 2001).

The mapará is a fast-growing fish that may reach a body length of $55 \mathrm{~cm}$ with a lifespan of a little over five years, and high natural mortality rates (Cutrim \& Batista 2005). This species has high fecundity (Costa, 2006) and piecemeal spawning (Benedito-Cecílio and Agostinho, 1991), with reproductive patterns varying regionally. On the lower Tocantins River, for example, H. marginatus spawns at the beginning of the flood season (Carvalho \& Merona, 1986; Hainfellner, 2015), whereas in the Tucuruí reservoir (Cintra et al., 2008) and on the Amazon River (Carvalho, 1980; Isaac et al, 1995), reproduction occurs at the peak of the flood. The biological characteristics of the species are consistent with those of an ecological $r$-strategist, which may make it more tolerant of fishery pressure (Adams, 1980). However, H. marginatus suffers very intense pressure on both the Amazon (Costa et al., 2010) and lower Tocantins (Cutrim \& Batista, 2005) rivers, which has already led to a progressive reduction in catches.

The mapará is an economically-important fishery resource in the Brazilian Amazon region (Cutrim, 2005), with an annual catch of 9-10 thousand tons (MPA, 2012), and is normally among the principal species landed at fishery ports on the Amazon and Tocantins rivers (Isaac et al., 2000; Ruffino et al., 2006; Cintra et al., 2007; Gonçalves \& Baptista, 2008). Hypophthalmus marginatus is sold fresh or salted and dried, and is in high demand around the world, representing a valuable 
export, which competes with more traditional products such as the salt cod from the North Sea. The trade-in dried and salted mapará is relatively profitable, given that the product does not require refrigeration, reducing considerably the costs of storage and transportation (Medina Vivanco, 2003).

Traditional mapará fisheries are found throughout the Tocantins basin, using seines and gillnets, either fixed or drifting (Cetra \& Petrere, 2001; Cintra et al., 2009; Merona et al., 2010; Silva et al., 2021). The formation of shoals facilitates fishing by increasing the capturability of the species (Carvalho \& Mérona, 1986). The most traditional mapará fishery on the Tocantins is the seine, known locally as the "borqueio". This technique is adapted to the tidal inversion zone of this river and is unique to the lower Tocantins (Merona et al., 2010).

The borqueio is based on nets $200-400 \mathrm{~m}$ in length and $9 \mathrm{~m}$ high, with a small mesh of $20 \mathrm{~mm}$ or $25 \mathrm{~mm}$. The technique involves 15-30 fishers, 5-10 dugouts, two larger canoes, and one or two motorboats (Merona, et al., 2010). The fish are captured in three stages: (i) identification of a shoal, (ii) fishing, and (iii) landing of the catch. As described by the local fisher, Raimundo Pureza, "The fishery is known as the borqueio, which is common in the region, begins which the spotting of a shoal by a professional known as a stalker ("taleiro"), who sounds out the location of the fish using a pole. Once the shoal has been spotted, the stalker calls the gang (the group of fishers), who open the nets, and then circle round to join the two ends, when the fish are retrieved from the net" (Dourado, 1993 apud Colônia De Pescadores Z-15, 2006). It is clear that the success of the operation depends on the knowledge, experience, and perceptiveness of the stalker, who needs to assess the size and quality of the shoal, as well as the participation of experienced fishers, who need to close the seine rapidly before the fish can escape.

In Brazil, the mapará fisheries of the Amazon region are subject to a number of regulations. In the specific case of the Tocantins basin, the principal regulation is inter-ministerial normative instruction number 13 of October 11th, 2011, which establishes the period of the closed season, during which the harvesting of the mapará is prohibited, between November 1st and February 28th, a period that covers spawning throughout most of the region. In the specific case of the lower Tocantins, this period coincides almost exactly with the spawning season of H. marginatus (Carvalho \& Merona, 1986; Isaac et al., 1993; Hainfellner, 2015). This same regulation also prohibits gillnetting with a mesh of less than $70 \mathrm{~mm}$, and also seine nets. This legislation is based on the observation that small meshes and seine nets tend to capture small fish, that is, immature individuals, which may impact the long-term sustainability of the fisheries, and threaten the integrity of stocks.

One other important regulation in the region is the NATURATINS State Decree number 319 of August 24th, 2016, which permits the harvesting of the mapará within the hydrographic basins of the Araguaia and Tocantins rivers, and their tributaries, lakes, floodplain lakes, reservoirs, and other bodies of water, as long as the fish is at least $30 \mathrm{~cm}$ long. This regulation is designed to contemplate the mean size of $H$. marginatus at first sexual maturation $\left(\mathrm{L}_{50}\right)$. However, estimates of $\mathrm{L}_{50}$ for the mapará vary among areas. For example, Cintra et al (2008) recorded a value of $41 \mathrm{~cm}$ for the Tucuruí reservoir, while Carvalho (1978) registered $37 \mathrm{~cm}$ on the middle and lower Tocantins, in Pará, and Alcântara Neto (1994) recorded an $\mathrm{L}_{50}$ of $27 \mathrm{~cm}$ on the lower Amazon.

These data indicate, then, that the current fishery regulations are at least partly discordant with the local traditions of the mapará fisheries of the Tocantins River. The fisheries are based on the use of gillnets as seines, with meshes of 20-25 mm, so both the type of net and the mesh size are prohibited by the legislation.

Considering the frequent confiscations and fines applied by both state and federal fishery monitoring agencies on the lower Tocantins, the present study investigated the pertinence of the existing legislation on the mapara fisheries and sought to provide practical insights for the adjustment of the regulations to the local reality.

This study is the result of the demands of local fishers, who believe that their fishery practices are consistent with the aims of conservation and sustainable management, and requested the present research as a means of supporting their arguments, 
to prove that in the traditional mapará fishery is not the gillnets size which select the size of the fish but instead, the fishermen knowledge.

In this context, we aimed specifically to answer to questions: a) is the mapará fishery of the Tocantins targeting only young individuals, so that, in addition to being illegal, it may be threatening the sustainability of stocks? and b) is the gillnet size capturing individuals with less than $30 \mathrm{~cm}$ of body size, which is against the regulation? The results of the study will be important for the validation of the fishery regulations, and to update the measures that aim to guarantee the conservation of stocks.

\section{Materials and Methods}

\subsection{Study area}

The data were collected on the Pindobal Grande River, a tributary of the Tocantins River in the municipality of IgarapéMiri, located downriver from the Tucuruí hydroelectric dam (Figure 1). Igarapé-Miri has a population of 60,994 inhabitants (IBGE, 2017), and the local economy is based on the harvesting of açaí (Euterpe oleracea) and artisanal fisheries, principally for shrimp and the mapará. The town of Igarapé-Miri is the municipality's most important urban center, with the rest of the population residing in small villages or along the margins of the local rivers, which are dominated by floodplain forests, with extensive natural tracts of açaí palm. The local rivers reach their maximum level between March and May, and low water between August and October.

\subsection{Data collection}

The data were collected during the mapará fishery, immediately following the closed season, for one day at the beginning of April 2016, on the Pindobal Grande River. This river is located in the vicinity of Pindobal Grande village, in the municipality of Igarapé-Miri, which can only be reached by river (Figure 1). The collection of the data was supported by the members of the Z-15 Fishery Cooperative of Igarapé-Miri, which, among other facilities, has a boat that is used for fishing. The mapará was harvested by a team of local fishers, with the authors remaining in the boat to record the observations and collect samples of the fish harvested. Information's about the techniques and knowledge use on the local mapará fishery was obtained through informal interviews with the fishers. 
Figure 1. Location of Pindobal Grande River in northeastern Pará, where the data on the mapará harvest was collected in the present study.

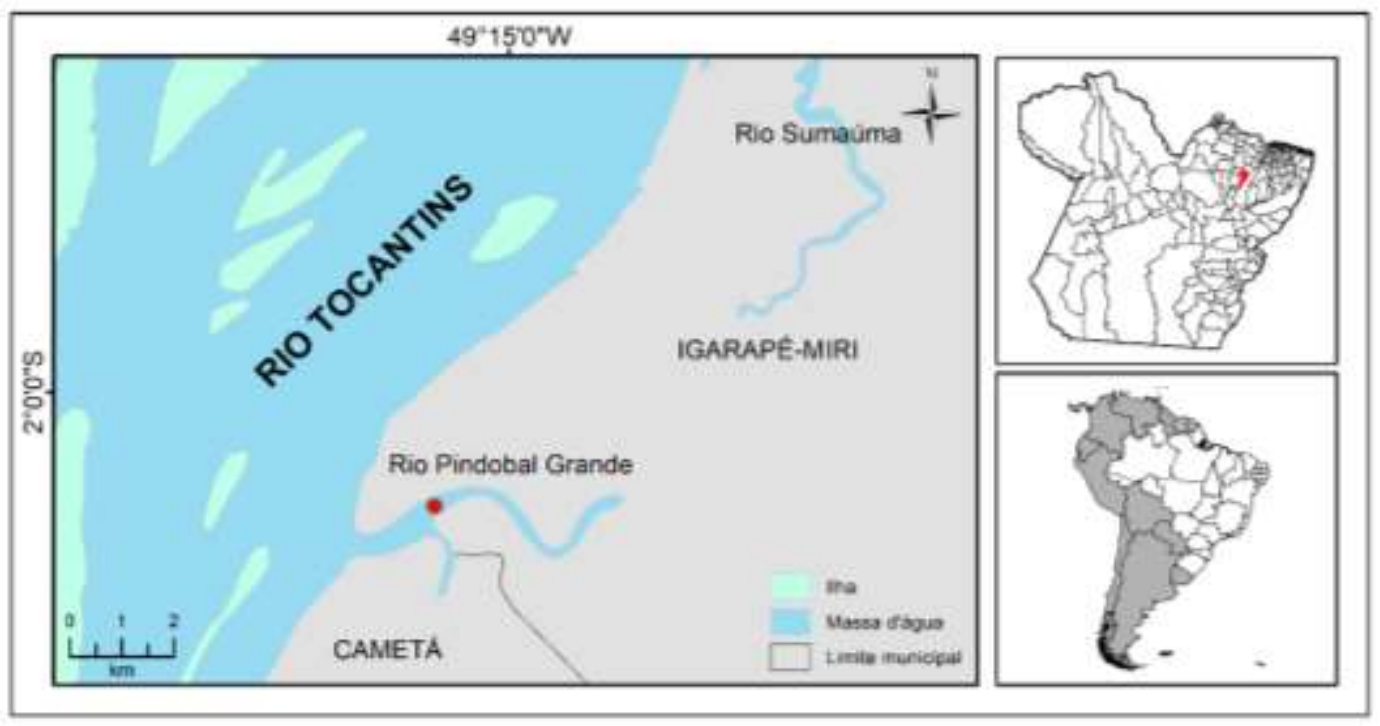

Source: Authors.

During the observations, we took two baskets of fishes from the total of around 40 baskets landing, each basket weighing $30-40 \mathrm{~kg}$, with a total of 388 individuals from only one landing. All of the specimens sampled were identified and measured (total length, in cm: length from the tip of the snout to the posterior extremity of the longest ray of the caudal fin), and weighed (g). An abdominal incision was made to access the gonads, determine the sex of the individual, and record the maturation stage of the gonads, based on the classification of Vazzoler (1996).

\subsection{Data analysis}

We use our own observations and the explanations the fishermen gave to us during the fishery to describe the fishery activity, since direct observation allows us to have a holistic environmental overview with researchers contribution, using the traditional knowledge passed on by the community, to bring together scientific knowledge and the perspective of the community's fishermen it is possible to fill in the knowledge gaps and come up with more effective management measures (BERKES, 2004; KOHLER and BRONDIZIO, 2017). The fish data were processed for the production of basic descriptive statistics, including the sex ratio and the distribution of maturation classes. Sex ratios were tested using Chi-square, and the differences between the mean total length of males and females were assessed using Student's t, with $\alpha=5 \%$ being considered in both cases. The results were compared with data from previous studies and evaluated in the context of the existing fishery legislation.

\section{Results}

\subsection{Fishing techniques for the mapará on the lower Tocantins}

The mapará harvest begins each year at the first moon or spring tide following the closed season, which is normally in March. The first day of the fishery is a community event that attracts many local visitors, and even tourists from further af ield (SETUR/PA, 2018). The harvest continues until October each year, with each group of fishers working on a fortnightly schedule. Seven local communities are involved in the mapará fisheries in this region of the lower Tocantins, Pindobal Grande, Alto 
Anapu, Pindobal Miri, Baixo Anapú, Tanacauera, Juairimbu, and Pindobalzinho. Each community has a group of approximately 20 fishers, with a total population of at least 140 fishers.

The activity begins early, at around 5 a.m., with the fishers arriving from all directions and coming together at the predetermined meeting point. Thirty-six fishers were observed participating in the capture of the mapará, and these individuals separated into distinct groups during the course of the day, in accordance with their roles in the fishery.

A group of six stalkers (taleiros) was the first to leave the meeting point. These individuals were responsible for the identification of mapará shoals moving upriver. This activity requires a great deal of experience, and thus typically involves the older fishers, aboard canoes, who row slowly along the river against the current, probing the water with their wooden poles (Figure 2A). These poles or "talas" are up to 7 meters long and 2-3 cm thick. The stalkers are able to discern, from the type, intensity, and a number of times the pole is hit, whether the fish is the mapará, the size of the shoal, and the average size of the individuals in the shoal. This procedure guarantees the performance of the deployment of the seine and optimizes the efforts of the whole team. An experienced taleiro can even estimate reliably how many baskets of fish will be extracted from a shoal.

The rest of the fishers follow on behind the taleiros in their own canoes, which contain baskets. The two larger canoes carry the net, with half in each boat. It is important for this group to maintain its distance from the taleiros, to avoid spooking the shoal of mapará. Once the taleiros confirm the location of a shoal, the fishers move rapidly to the place indicated. The fishers in the two large canoes then deploy the net (Figures 2B, 2C), and row in opposite directions to form and then close a circle around the shoal. Simultaneously, the other fishers begin to beat the water with their hands, in a movement known as a "carolina" in an attempt to drive the shoal toward the net. The seine is deployed from the deeper part of the river toward the margin, given that, according to the fishers, the fish spooked by the movement in the water tend to flee toward the deeper parts of the channel. The circle is known as the "borqueio", which is in fact, a mispronunciation of the Portuguese word "bloqueio" or "blockage".

Once the circle is closed, the third group, the divers, enters into action (Figure 2D). These fishers, approximately 11 men, who position themselves around the outside of the net and help narrow the circle by diving to the bottom of the net to push the weights at the bottom and help stop the fish escaping. At the same time, they force the fish toward the center of the net, where the mesh os smaller. This procedure is known as the "entralhamento" or harnessing, during which the divers may reach depths of up to $10 \mathrm{~m}$, without the use of airlines. 
Figure 2. A) Stalkers (taleiros) searching for a shoal of mapará; B) Seine nets in the canoes; C) Fishers deploying the net; D) Operation of the net, with the participation of divers.

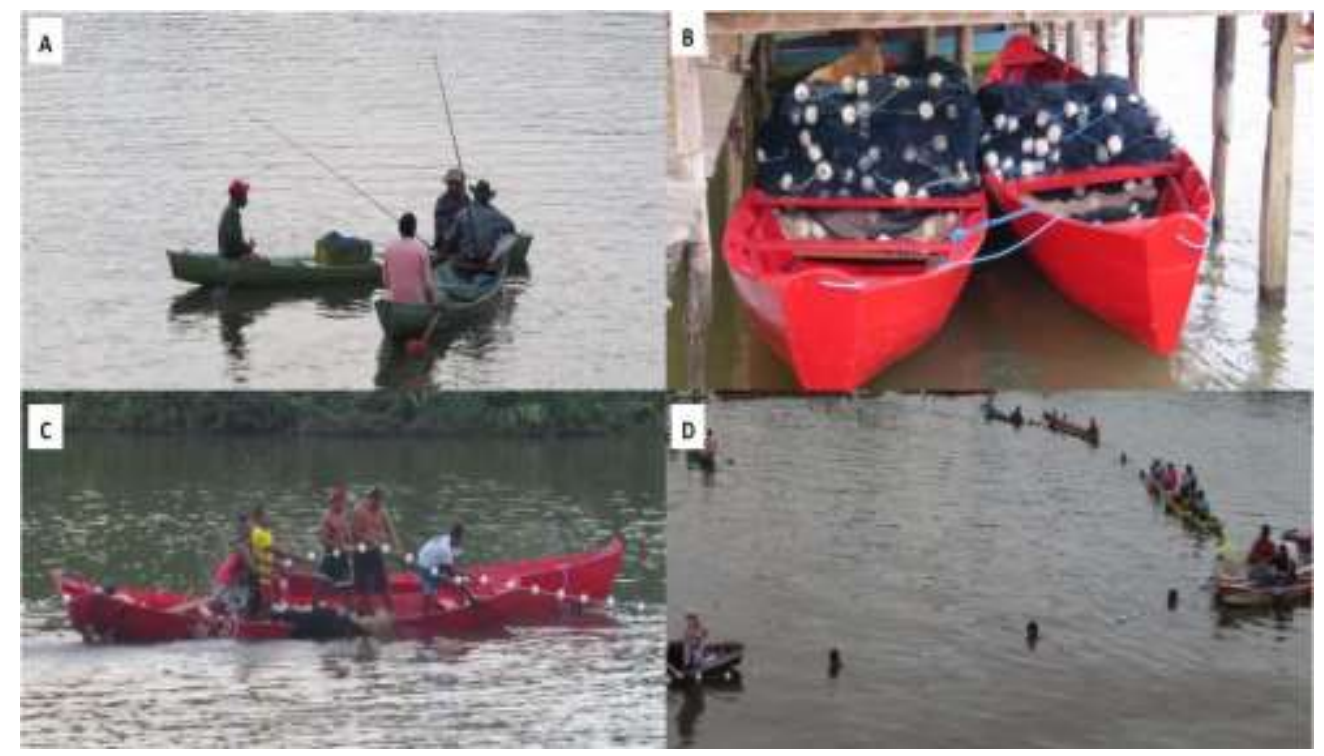

Source: Authors.

When the circle is well closed in (Figures 3A, 3B), the divers begin to "sew-up" the bottom of the net with a cord that they pass from one side to the other until the two ends are brought together. This is repeated until the net is completely closed and can be raised to haul the shoal to the surface (Figure 3C). At this moment, the fish are retrieved from the river, and placed in the canoes, using baskets (Figure 3D), which allow the excess water to run off.

The net used in this seine fishery is made of nylon multifilament and is approximately 400 meters long and $9 \mathrm{~m}$ or more high, with meshes varying from $20 \mathrm{~mm}$ to $25 \mathrm{~mm}$, from the center to the ends, respectively. The central part of the net, which has a smaller mesh, is known as the "apertadeira" or squeezer and concentrates the shoal at the end of the operation. The master line is found in the upper part of the net, with styrofoam buoys that keep the net afloat, while lead weights are attached to the bottom of the net, to keep it in place. The net does not work by trapping the fish by the gills, but rather by impeding the escape of the fish from the seine. In fact, great care is taken to avoid the trapping of the fish by the net, as this may cause small wounds, which will reduce the quality of the fish, and its market value.

The catch is divided into two equal parts: (i) half is divided equally among all the residents of the community, including those not involved directly in the fishery, and (ii) the other half is divided between the owners of the nets (25\%) and the fishers (25\%), with $10 \%$ of the earnings of the net owners being destined for the payment of the taleiros. This division of benefits was established through an agreement reached by the fishers of the Z-15 Cooperative of Igarapé-Miri, in 1991, and has been maintained to the present day, and is applied throughout the mapará harvest. The catch is sold directly to the fish markets in the neighboring towns of Igarapé-Miri, Abaetetuba, Baião, and Anapu. The fishery is conducted every fortnight by each group of fishers. 
Figure 3. Seining for mapará. A) Formation of the circle, B) and C) Closing the seine; D) Removal of the fish from the net.

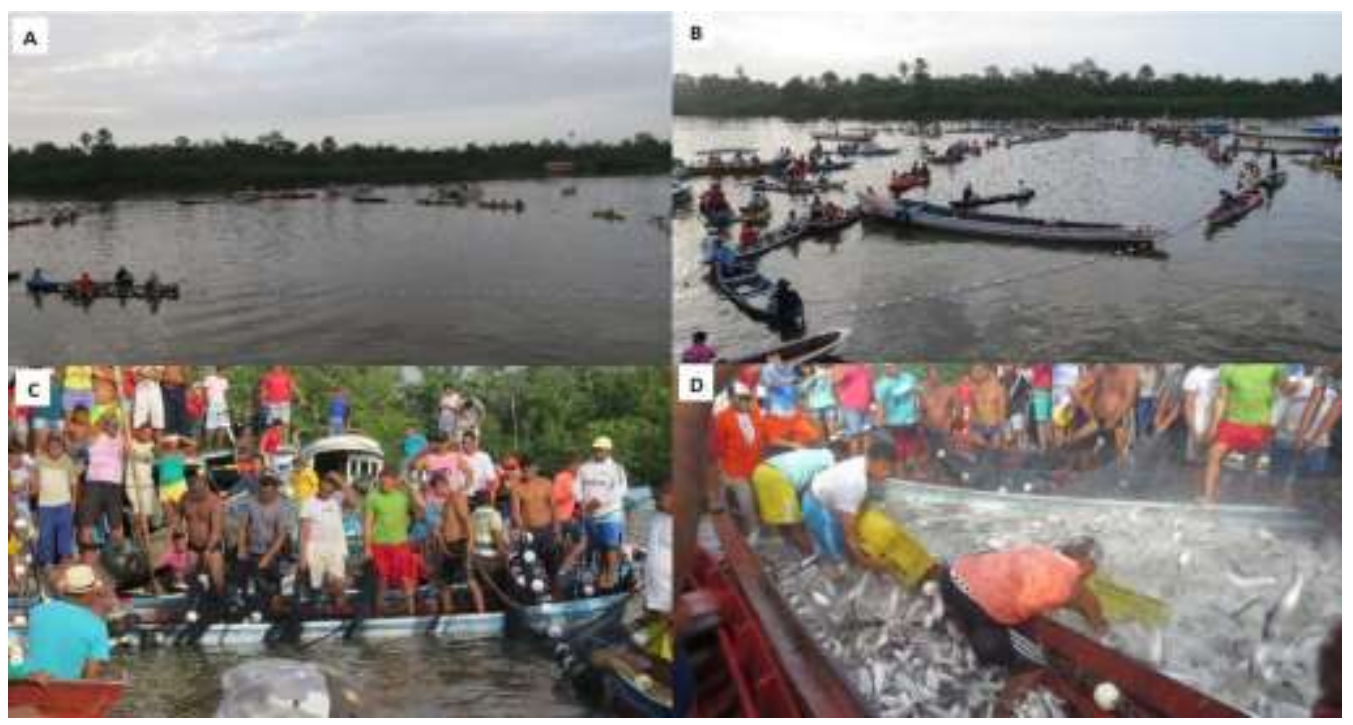

Source: Authors.

\subsection{Size structure of the catch}

A total of 388 individuals were analyzed, representing a total weight of approximately $72 \mathrm{~kg}$ of mapará. All the fish caught during this study belonged to the species $H$. marginatus, which means that the fishery was truly monospecific.

The total length of the fish varied from $23 \mathrm{~cm}$ to $41 \mathrm{~cm}$, with a mean length of $34 \mathrm{~cm}$, and a standard deviation of 3.34 $\mathrm{cm}$. Only $5 \%$ of the 388 individuals harvested had a total length of less than $30 \mathrm{~cm}$. At least five modal classes can be observed in the distribution of the length classes (Figure 4), which indicates the possible existence of a number of different age classes in the sample.

Figura 4 Number of mapará caught during the present study, by length class $(\mathrm{cm})$. The vertical red line represents the minimum size of capture established by the current fishery legislation.

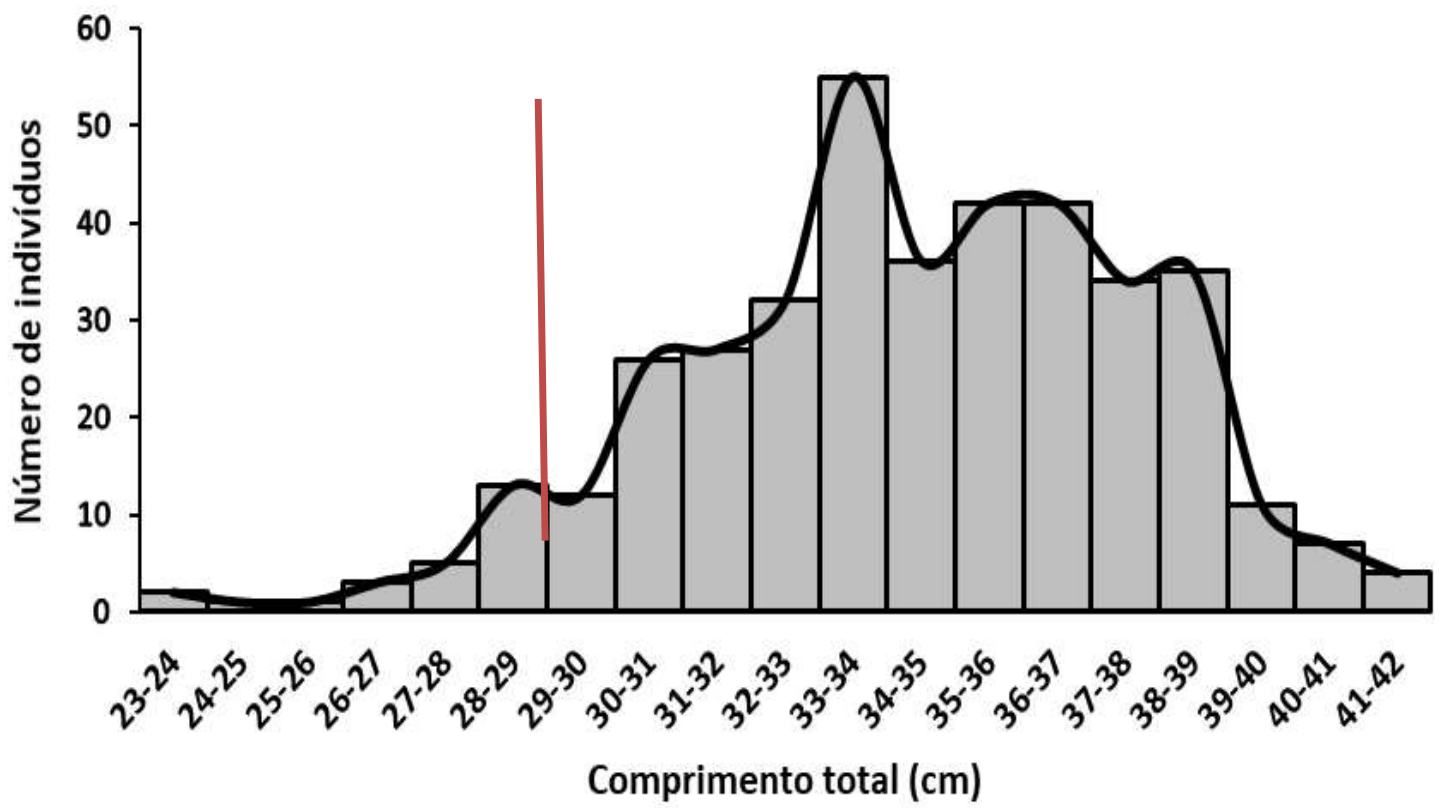

Source: Authors. 
It was not possible to sex around $62 \%$ of the fish due to the small size of their gonads, which indicated that they were either juvenile or were reproductively inactive. Of the other $38 \%$ of the fish, $24 \%$ were male, and $14 \%$, female, with a female: male sex ratio of 1:1.75. No significant variation (Student's $t: p=0.92$ ) was found in the mean total length between the males (mean total length: $35.2 \mathrm{~cm}$ ) and females $(33.6 \mathrm{~cm}$ ). The analysis of the gonads indicated that $90 \%$ of the individuals were immature or reproductively inactive, and the other $10 \%$ were in the maturation stage, which indicates clearly that April does not coincide with the breeding season of H. marginatus on the lower Tocantins.

\section{Discussion}

Gillnets capture fish in four different ways, that is, by getting the fish stuck, entangled, netted or hitched, although none of these processes occur in the mapará fishery, given that the net is used only to aggregate the shoal within a confined space, rather than trapping the fish in the net. In fact, as this would "hurt" the fish and reduce its commercial value, it is not in the fishers' interest to have the fish entangled in the net, which is used to justify the use of nets with relatively small mesh sizes. If the mapará fishers adhered strictly to the regional legislation and used nets with a mesh of no less than $70 \mathrm{~mm}$, the fishery would be far less productive or profitable, and would probably lead to a much larger number of "hurt" fish being discarded.

While the use of nets with meshes of less than $70 \mathrm{~mm}$ may result in the capture of very young, juvenile fish, and thus impact recruitment, the vast majority (90\%) of the H. marginatus caught in the present study had a total length of more than 30 $\mathrm{cm}$, which is the minimum permitted size under the current legislation. Merona et al. (2010) concluded that this type of fishery targets shoals of juvenile mapará, that are moving upriver to spawn, although the data available on the size of H. marginatus at first maturation are inconclusive, and this parameter requires more systematic investigation before being used as the criterion for the establishment of regulatory norms.

We can conclude, however, that, despite its use of prohibited gill nets, meshes that are too small, and a fishing technique not allowed in inland waters, the mapará fisheries of the Tocantins River are extremely selective, with the gillnets being adapted in a way that eliminates bycatch and renders a catch of mapará of legal size $(<30 \mathrm{~cm})$. Merona et al. (2010) observed that more than $97 \%$ of the fish caught using the block netting technique in the study region were mapará, while in the present study, all the fish caught were H. marginatus.

The adaptation of the net to the local environment and the target species, together with the experience and knowledge of the taleiros, who have a profound understanding of the characteristics of the mapará (in particular, the formation of shoals by age cohort), and the spatiotemporal distribution of its shoals, has resulted in the development of fishery techniques on the lower Tocantins that guarantee optimal productivity without impacting the conservation of the species. Merona et al. (2010) compared the catches of mapará on the lower Tocantins prior to and after the construction of the Tucuruí hydroelectric dam, and concluded that the fishers themselves regulate the mapará harvest by alternating the catches of $H$. marginatus with other target species, such as the croakers (family Sciaenidae), when the mapará becomes scarce on the river.

Recently, there has been growing interest in the concept of "intellectual property rights" as applied to local and traditional knowledge. The FAO Code of Conduct for Responsible Fisheries (FAO, 1995), for example, emphasizes the need for the recognition of traditional knowledge. The most appropriate approach in the present case would be to improve the exchange of information between communities and the environmental institutions, in order to ensure the formulation of adequate policies of sustainable development.

The importance of traditional knowledge and its value for humankind is subject to a multitude of myths, opinions, and facts. The fishery sector has a considerable wealth of traditional knowledge, which is reflected in its belief systems and lifestyles. The knowledge of fishers with regard to the natural environment and the behavior of the fish they harvest is a key element for the optimization of artisanal fisheries. This knowledge can permit the use of practices that simultaneously guarantee the integral 
exploitation of natural resources, while also permitting ecosystem-level management measures that can maximize the economic benefits of the activity (Berkes et al., 2000; Begossi et al., 2008; Silvano \& Valbo-Jørgensen, 2008; Carvalho et al., 2021).

The regulations that control Brazilian fisheries have traditionally been based on a technocratic approach, with measures being implemented by government entities that are geographically distant from the local communities and have little understanding of local needs or the unique features of each fishery, while also lacking the reliable, long-term data necessary for the adequate application of management actions (Isaac et al., 1998). The inadequate application of regulations that overlook the local features of Amazonian fisheries has drawn attention in a number of previous studies (Isaac et al. 1993; Kalikoski et al., 2006) and has led many fishers to make their own decisions on the most appropriate strategies for the sustainable exploitation of local natural resources, through different levels of participative management and community organization (Mcgrath et al., 1993; Castro; Mcgrath, 2001; Azevedo; Apel, 2004; Almeida et al., 2009; Castello et al., 2011; Oviedo et al. 2015; Ferreira; Silva, 2017; Goulding et al., 2018).

By overlooking the traditional knowledge of local fishers and their potential for the management of local resources in the decision-making process on the implementation of fishery regulations, the government entities assigned to the protection of natural resources induce illegal practices and the loss of their authority at the community level. This destabilizes the fishery governance system and, ultimately, contributes to a decrease in the sustainability of this activity (Isaac et al., 1993; Johannes et al., 2000; ST. Martin, 2006; Pryshon; Cunha; Dias., 2019). This authoritative approach to the regulation of the fisheries reflects the belief that the fishers are incapable of understanding the ecological system and the measures necessary to regulate their fishery activities to guarantee their long-term sustainability (Mcgoodwin, 2000). This appears to be the case of the mapará fisheries on the lower Tocantins.

Fishery legislation should be applied specifically to each region, and not just in relation to the scientific information available on the target species, but rather, it should take into consideration the traditional local knowledge on the ecology, behavior, and classification of the fish held by the local fishers, which maximize the efficiency of the local fishing strategies that help guarantee the subsistence of the community (Silvano, 2004; Pilgrim et al., 2007; Silva \& Silva., 2020). In this context, participative management is clearly the most effective approach for the resolution of many of the conflicts associated with the traditional technocratic model of fishery management, due to the incorporation of the users of local natural resources in the decision-making process (Oviedo et al., 2015).

In the present study, then, despite the fact that the mapará fishery is considered illegal in relation to a number of different aspects of the current legislation, the activity does not contradict any of the objectives of the legislation. In other words, the results of the study indicate that neither of the prohibitions, on the fishing technique (block-netting) or mesh size $(<70 \mathrm{~mm})$ were pertinent to the mapara fishery of the lower Tocantins, given that the vast majority of the fish harvested satisfied the minimum size (total length of $\geq 30 \mathrm{~cm}$ ) criterion. It is thus essential that the existing legislation is reviewed with the collaboration of the members of the Z-15 Fishery Cooperative at Cametá for the effective conciliation of the twin aims of ecosystem conservation and socioeconomic development, with the fundamental objective of improving the quality of life of the region's inhabitants.

\section{Conclusion}

The "taleiro" within the low Tocantins fishing activity is responsible by the selectivity of mapara catfish fishery, saving the youngest individuals of the population, and thus, keeping the resources sustainability. It is essential that the existing legislation should be reviewed with the Z-15 Igarapé-Miri fishermen collaboration aims the effective conciliation of the both aims of ecosystem conservation and socioeconomic development, with the fundamental objective of improving the life quality of the region's inhabitants. Recognizing the importance of traditional knowledge to corroborate future research, in addition using 
the social actor's observation who are directly in ecosystem contact and the scenario to be investigated are of great value. It's a good alternative to construct together, a better adaptive regulation that could benefit the development of preventive measures aimed to the perpetuation of fish stocks and fishing activity.

\section{Acknowledgments}

We are grateful to the Z-15 Fishery Cooperative and the fishers who helped us and collaborated with all of the logistical support to carry out this work, especially to Mr. Rosinho

\section{References}

Abelha, M. C. F., Agostinho, A. A. \& Goulart, E. (2001). Plasticidade trófica de água doce. Acta Scientiarum, 23, 425 - 434. 10.4025/actascibiolsci.v23i0.2696 Adams, P. B. (1980).Life history patterns in marine fishes and their consequences for fisheries management. Fisheries Bulletin, $78,1-12$.

Almeida, O. T., Lorenzen, K. \& Mcgrath, D. G. (2009). Fishing agréments in the lower Amazon: For gain and restraint. Fisheries Management and Ecology, 16, 61 - 67. doi.org/10.1111/j.1365-2400.2008.00647.x

Azevedo, C. R. \& Apel, M. (2004). Co-gestão: Um processo em construção na várzea amazônia. Manaus: ProVárzea/IBAMA.

Barthem, R. \& Goulding, M. (1997). Os bagres balizadores: ecologia, migração e conservação de peixes Amazônicos. Manaus - AM: Sociedade Civil Mamiauá. Benedito-Celílio, E. \& Agostinho, A. A. (1991). Biologia reprodutiva de Hypophthalmus edentatus (Spix, 1829) (osteichthyesm Siluriformes) no reservatório de Itaipu-PR. UNIMAR, 13, $211-227$.

Berkes, F. (2004). Rethinking community-based conservation. Conservation biology, 18(3), 621-630.

Berkes, F., Colding, J. \& Folke, C. (2000). Rediscovery of Traditional Ecological Knowledge As Adaptative Management. Ecological Applications, 10, 1251 1262. 10.1890/1051-0761(2000)010[1251:ROTEKA]2.0.CO;2

Begossi, A., Clauzet, M., Figueiredo, J. L., Garuana, L., Lima, R. V., Lopes, P. F., Ramires, M., Silva, A. L., \& Silvano, R. A. M. (2008). Are biological species and higher-ranking categories real? Fish folk taxonomy on Brazil's Atlantic Forests coast and in the Amazon. Current Anthropology, 49,291 - 306.

Carvalho, T. C. C., Barros, M. R. F., Ramos, Á. J. R., dos Reis, A. R., Melo, A. A. D., Palheta, S. C. M. G., Carvalho, A.S.S., \& Palheta, G. D. A. (2021). Socioeconomia e etnoconhecimento de pescadores artesanais da comunidade do Cajueiro, distrito de Mosqueiro, Amazônia Oriental. Research, Society and Development, 10(2), e12410212336-e12410212336.

Carvalho, F. M. (1980). Alimentação do mapará (Hypophthalmus edentatus Spix, 1829) do lago do Castanho, Amazonas (Siluriformes, Hypophthalmidae). Acta Amazonica, 10, 3. dx.doi.org/10.1590/1809-43921980103545

Carvalho, J. L., \& Merona, B. (1986). Estudo sobre dois peixes migratórios do baixo Tocantins, antes do fechamento da barragem de Tucuruí. Amazoniana, 9 , $595-607$.

Castello, L., Pinedo-Vasquez, M. \& Viana, J. P. (2011) Participatory conservation and local knowledge in the Amazon várzea: the pirarucu management scheme in Mamirauá. In: Pindedo-Vasquez, M., Ruffino, M., Padoch, C. J., \& Brondízioo, E. S. The Amazon Varzea: The decade past and the decade ahead. New York - NY: Springer-Verlag.

Castro, F. \& McGrath, D. G. (2001). O manejo comunitário de lagos na Amazônia. Parcerias Estratégicas, 12,112 - 126.

Cetra, M. \& Petrere Jr, M. (2001). Small-scale fisheries in the Middle River Tocantins, Imperatriz (MA). Fisheries Management and Ecology, 8,153 - 162. doi.org/10.1046/j.1365-2400.2001.00233.x

Cintra, I. H. A., Juras, A. A., Andrade, J. A. C. \& Ogawa, M. (2007). Caracterização dos desembarques pesqueiros na área de influência da Usina Hidrelétrica de Tucuruí, Estado do Pará, Brasil. Boletim Técnico-Científico do CEPNOR, 7: 135-152.

Cintra, I. H. A., Pinheiro, J. C. da R., Juras, A. A., Souza, R. F. C. \& Ogawa, M. (2008) Biologia do mapará, Hypophthalmus marginatus (Valenciennes, 1840), no reservatório da Usina Hidrelétrica de Tucuruí (Pará-Brasil). Boletim Técnico-Científico do CEPNOR, 8(1): 83-95.

Colônia de pescadores Z-15. (2006). Acordos de pesca em Igarapé Mirim / Colônia de pescadores Z-15. MMA. 44 p. il. color. 27,5 cm. (Série Sistematização, v. IV)

Costa, T. V. da. (2006). Identificação de novas espécies com potencial para a criação em cativeiro: pescado capturado no Estado do Amazonas. Dissertação (Mestrado em Zootecnia) - Universidade Federal Rural do Rio de Janeiro, Rio de Janeiro.

Costa, T. V. da, Oshiro, L. M. Y. \& Silva, E. C. S. (2010). O potencial do mapará Hypophthalmus spp. (Osteichthyes, Siluriformes) como uma espécie alternativa para a piscicultura na Amazônia. Boletim Instituto de Pesca, 3, 165 - 174.

Cutrim, L., \& Batista, V. S. (2005). Determinação de idade e crescimento do mapará (Hypophthalmus marginatus) na Amazônia Central. Acta Amazônica, 35, 85 - 92. dx.doi.org/10.1590/S0044-59672005000100013 
Ferreira, R. R., \& Silva, R. E. (2017). Acordo de Pesca como gestão dos recursos: O caso da ilha de São Miguel, Santarém, Pará. Amazônica, Revista de Antropologia, 9, 156 - 178. dx.doi.org/10.18542/amazonica.v9i1.5487

FAO. (1995). Code of Conduct for Responsible Fisheries Rome, FAO. $41 \mathrm{p}$

Goulding, M., Venticinque, E., Ribeiro, M. L. D. B., Barthem, R. B., Leite, R. G., Forsberg, B., Petry, P., Silva-Júnior, U.L., Ferraz, P.S., \& Cañas, C. (2019). Ecosystem-based management of Amazon fisheries and wetlands. Fish and Fisheries, 20(1), 138-158.

Gonçalves, C., \& Baptista, V. S. (2008). Avaliação do desembarque pesqueiro efetuado em Manacapuru, Amazonas, Brasil. Acta Amazônica, 38 , 135 - 144. dx.doi.org/10.1590/S0044-59672008000100015

Hainfellner, P. (2015). Ciclo reprodutivo e indução hormonal de fêmeas de mapará (Hypophthalmus marginatus) no baixo Rio Tocantins, à jusante da barragem de Tucuruí. Tese (Doutorado em Aquicultura) - Universidade Estadual Paulista, São Paulo.

Isaac, V. J., Rocha, V. L. C. \& Mota, S. (1993). Considerações sobre a legislação da 'piracema' e outras restrições da pesca na região do médio Amazonas. In: Furtado, L., Leitão, W., \& Mello, F. Povos das Águas - realidade e perspectivas na Amazônia. MCT/CNPq/MPEG.

Isaac, V. J., \& Barthem R. B. (1995). Os recursos pesqueiros da Amazônia brasileira. MPEG.

Isaac, V. J., Ruffino, M. L. \& McGrath, D. (1998). In search of a new approach to fisheries management in the middle amazon. In: Funk, F., Heifetz, J., Janelli, J., Power, J., Quinn, T., Schweigert, J., Sullivan, P. J. \& Zhang, C. I. (1998). Fishery stock assessment models for the $21^{\text {st }}$ century. Anchorage - AK: Alaska Sea Grant College Program No. AK-SG-98-01.

Isaac, V. J., Ruffino, M, L. \& Mello, P. (2000). Considerações sobre o método de amostragem para a coleta de dados sobre a captura e esforço pesqueiro no Médio Amazonas. In: Fischer, C. F. A. Recursos Pesqueiros do Médio Amazonas: biologia e estatística pesqueira. IBAMA.

Johannes, R. E., Freeman, M. M. R. \& Hamilton, R. J. (2000). Ignore fishers knowledge and miss the boat. Fish and Fisheries, 1, 257 - 271. doi.org/10.1111/j.1467-2979.2000.00019.x

Juras, A. A., Ludovino, R. M. R., Cintra, I. H. A. (2005). A pesca do mapará no Lago de Tucuruí, p. 135-138, in Oliveira, G.M. (org.), Pesca e aqüicultura no Brasil, 1991/2000: produção e balança comercial. Edições IBAMA, 259 p.

Kalikoski, D. C., Rocha, R. \& Vasconcello, M. C. (2006). Importância do conhecimento ecológico tradicional na gestão da pesca artesanal no estuário da Lagoa dos Patos, extremo sul do Brasil. Ambiente e Educação, 11, 87 - 118.

Kohler, F., \& Brondizio, E. S. (2017). Considering the needs of indigenous and local populations in conservation programs. Conservation Biology, 31(2), 245251.

Lowe-McConnell, R. (1987). Ecological Studies in Tropical Fish Communities (Cambridge Tropical Biology Series). Cambridge: Cambridge University Press. $10.1017 / \mathrm{CBO} 9780511721892$

Lundberd, J. G. \& Littmann, M. W. (2003). Pimelodilae (Long-whiskered catfishes). In: Reis, R. E., Kullander, S. O. \& Ferraris Jr, C. J. (2003). Checklist of the freshwater fishes of South and Central America. Porto Alegre - RS: EDIPUCRS.

McGoodwin, J. R., Neis, B. \& Felt, L. (2000). Integrating fishery people and their knowledge into fisheries science and resource management. Issues, prospects, and problems. In: Neis, B., Felt, \& L. Finding our sea legs: linking fishery people and their knowledge with science and management. Institute for Social and Economic Research.

McGrath, D. G., Calabria, J., Amaral, B., Futemma, C., \& Castro, F. (1993). Varzeiros, geleiros e manejo dos recursos naturais na várzea do Baixo Amazonas. Cadernos do NAEA, 11, $91-125$.

Merona, B., A. A., Juras, G. M. S. \& Cintra, I. H. A. (2010). Os peixes e a pesca no baixo rio Tocantins: vinte anos depois da UHE Tucuruí. [s.1]: Eletrobrás Eletronorte, 208p.

MPA, Ministério da Pesca e Aquicultura. Boletim Estatístico da Pesca e Aquicultura: 2011. 2012.

Oviedo, A. F. P., Bursztyn, M., \& Drummond, J.A. (2015). Agora sob nova administração: acordos de pesca nas várzeas da Amazônia Brasileira. Revista Ambiente \& Sociedade 18, 119-138. dx.doi.org/10.1590/1809-4422ASOC985V1842015

Prysthon, A., da Cunha, C. V., \& Dias, C. R. G. (2019). The fishing productivity assessement upstream and downstream of Tucuruí Hydroeletric Dam, TocantinsAraguaia basin, Brazil. Embrapa Pesca e Aquicultura-Artigo em periódico indexado (ALICE). 6(4).

Ruffino, M. L., Soares, E. C. S., Lopes-Junior, U., Estupinãn, G., Fonseca, S. N., Pinto, W. H., Oliveira, C., Barthem, R. B. \& Batista, V. (2006). Estatística Pesqueira do Amazonas e Pará 2003. Manaus: Ibama/ProVárzea.

Silva, B. H., Barbosa, S. M., Silva, P. F. M., \& Vasconcelos, A. S. (2021). Conflictos socioambientales en la pesca del mapará (Hypophthalmus marginatus): efectos de la represa Tucuruí. Reb. Revista de estudios brasileños I. 7(5), 179-193

Silva, T. E. \& Silva, M. R. F. (2020). A pesca, os pescadores e o etnoconhecimento da reserva de desenvolvimento sustentável estadual ponta do tubarão(RN)Brasil. Boletim de Geografia, 38(1), 56-72.

Silvano, R. A. M. \& Valbo-Jorgensen, J. (2008). Beyond fishermen's tales: contributions of fishers' local ecological knowledge to fish ecology and fisheries management. Environment, Development and Sustainability, 10, 657 - 675.

Vivanco, M. L. M. (2003). Desidratação osmótica em soluções ternarias, secagem e transições térmicas de filé de tilápia (Oreochromis niloticus). Tese (Doutorado em Engenharia de Alimentos) - Universidade Estadual de Campinas, São Paulo. 